This item is the archived peer-reviewed author-version of:

\title{
PPAR gene expression correlates with severity and histological treatment response in patients with Non-alcoholic Steatohepatitis
}

\section{Reference:}

Francque Sven, Verrijken An, Caron Sandrine, van Hul Wim, Mertens Ilse, Hubens Guy, van Marck Eric, Michielsen Peter, Van Gaal Luc, et al..- PPAR gene expression correlates with severity and histological treatment response in patients with Nonalcoholic Steatohepatitis Journal of hepatology - ISSN 0168-8278 - (2015), p. 1-45

DOI: http://dx.doi.org/doi:10.1016/j.jhep.2015.02.019 


\section{Accepted Manuscript}

PPAR $\alpha$ gene expression correlates with severity and histological treatment response in patients with Non-alcoholic Steatohepatitis

Sven Francque, An Verrijken, Sandrine Caron, Janne Prawitt, Réjane Paumelle, Bruno Derudas, Philippe Lefebvre, Marja-Riitta Taskinen, Wim Van Hul, Ilse Mertens, Guy Hubens, Eric Van Marck, Peter Michielsen, Luc Van Gaal, Bart Staels

PII: S0168-8278(15)00126-9

DOI: http://dx.doi.org/10.1016/j.jhep.2015.02.019

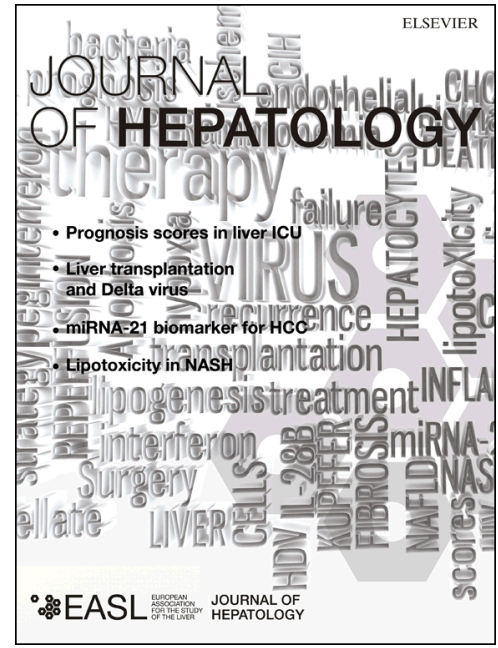

Reference: JHEPAT 5564

To appear in:

Journal of Hepatology

Received Date:

5 June 2014

Revised Date:

8 February 2015

Accepted Date:

10 February 2015

Please cite this article as: Francque, S., Verrijken, A., Caron, S., Prawitt, J., Paumelle, R., Derudas, B., Lefebvre, P., Taskinen, M-R., Van Hul, W., Mertens, I., Hubens, G., Van Marck, E., Michielsen, P., Van Gaal, L., Staels, B., PPAR $\alpha$ gene expression correlates with severity and histological treatment response in patients with Non-alcoholic Steatohepatitis, Journal of Hepatology (2015), doi: http://dx.doi.org/10.1016/j.jhep.2015.02.019

This is a PDF file of an unedited manuscript that has been accepted for publication. As a service to our customers we are providing this early version of the manuscript. The manuscript will undergo copyediting, typesetting, and review of the resulting proof before it is published in its final form. Please note that during the production process errors may be discovered which could affect the content, and all legal disclaimers that apply to the journal pertain. 


\section{TITLE PAGE}

2

3 Title:

4

5

$\operatorname{PPAR} \alpha$ gene expression correlates with severity and histological treatment response in

6 patients with Non-alcoholic Steatohepatitis.

7

8

9

10 Sven Francque* ( sven.francque@uza.be $)^{1,2}$

11 An Verrijken* (

12 Sandrine Caron ( sandrine.caron@inserm.fr $)^{4}$

13 Janne Prawitt ( janne.prawitt@inserm.fr ) ${ }^{4}$

14 Réjane Paumelle ( rejane.lestrelin@univ-lille2.fr $)^{4}$

15 Bruno Derudas ( bruno.derudas@ pasteur-lille.fr $)^{4}$

16 Philippe Lefebvre ( philippe-claude.lefebvre@inserm.fr ) ${ }^{4}$

17 Marja-Riitta Taskinen ( $\underline{\text { Marja-Riitta.Taskinen@ helsinki.fi })^{5}}$

18 Wim Van Hul (wim.vanhul@uantwerpen.be $)^{6}$

19 Ilse Mertens ( $\underline{\text { ilse.mertens@uza.be })^{2,3}}$

20 Guy Hubens (guy.hubens@uza.be $)^{7}$

21 Eric Van Marck (eric.van.marck@uantwerpen.be $)^{8}$

22 Peter Michielsen ( peter.michielsen@uza.be ) ${ }^{1,2}$

23 Luc Van Gaal ( luc.van.gaal@uza.be $)^{2,3}$

24 Bart Staels ( $\underline{\text { bart.staels@ } @ \text { pasteur-lille.fr })^{4}}$

25

26 *share first authorship 
28

29

$30{ }^{2}$ Laboratory of Experimental Medicine and Paediatrics, Faculty of Medicine and Health

31 Sciences, University of Antwerp, Antwerp, Belgium

$32{ }^{3}$ Department of Endocrinology, Diabetes and Metabolism, Antwerp University Hospital, 33 Antwerp, Belgium

34 3 36 37 38

49 Tel: 003238213323

50 Fax: 003238214478

51 E-mail: sven.francque@uza.be 
53 Electronic word count:

54 Abstract: 246

55 Main document: 4852

56

$57 \quad$ Numbers of Tables and Figures

58 Tables: 4

59 Figures: 1A-C, 2, 3

60

61 List of abbreviations:

62

63

ABT

Aminopyrine Breath Test

64

AFP

Alpha-fetoprotein

65

ALP

Alkaline Phosphatase

66

ALT

Alanine Aminotransferase

$67 \quad$ AST

Aspartate Aminotransferase

68 BMI

Body Mass Index

69 CPT1A

Carnitine Palmitoyl Transferase 1 Liver Isoform

$70 \quad$ CK 18

Cytokeratin 18

$71 \mathrm{CT}$

Computed Tomography

72 FGF21

Fibroblast Growth Factor 21

73 GGT

Gamma Glutamyl Transpeptidase

74 HBA1c

Glycosylated Haemoglobin

75 HDL

High Density Lipoprotein

76 HOMA

Homeostasis Model Assessment

77 IDF

International Diabetes Federation

$78 \mathrm{LDH}$

Lactate dehydrogenase 


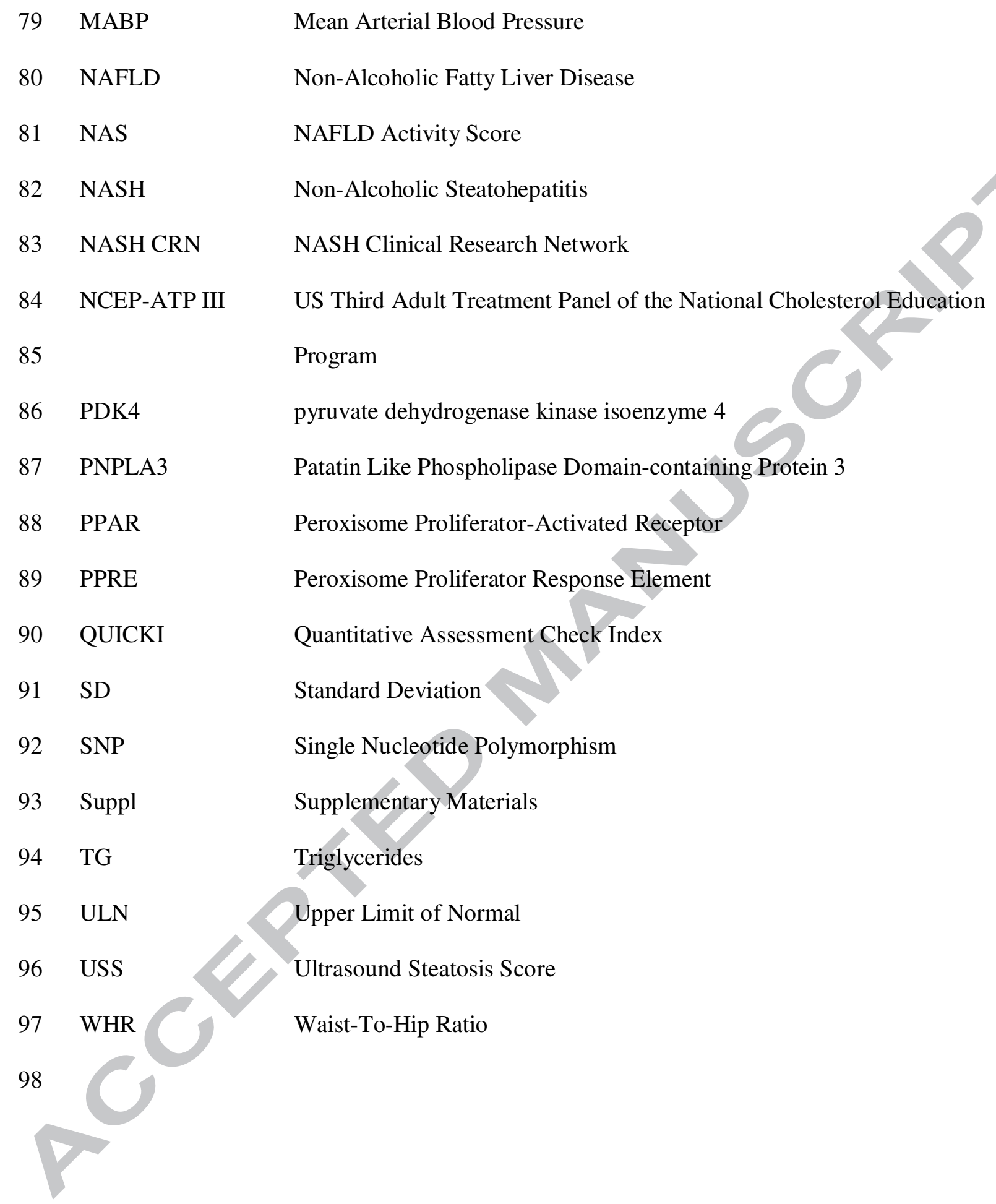


99

100 Non-alcoholic steatohepatitis; peroxisome proliferator-activated receptor; follow-up study;

101

102

103

104

105

106

107

108

109

110

111

112 Authors contributions:

113 Sven Francque: study concept and design, data acquisition, data analysis and interpretation,

114 draft of the manuscript

115 An Verrijken: data acquisition, data analysis and interpretation, draft of the manuscript

116 Sandrine Caron: data acquisition, data analysis and interpretation

117 Janne Prawitt: data acquisition, data analysis and interpretation

118 Réjane Paumelle: data acquisition, data analysis and interpretation

119 Bruno Derudas: data acquisition, data analysis and interpretation

120 Philippe Lefebvre: data acquisition, data analysis and interpretation

121 Marja-Riitta Taskinen:data acquisition, critical revision of the manuscript for intellectual

122 content

123 Wim Van Hul: data acquisition, critical revision of the manuscript for intellectual content

124 Ilse Mertens: data acquisition, data analysis 
125 Guy Hubens: critical revision of the manuscript for intellectual content

126 Eric Van Marck: data acquisition (pathology), critical revision of the manuscript for

127 intellectual content

128 Peter Michielsen: critical revision of the manuscript for intellectual content, study supervision

129 Luc Van Gaal: critical revision of the manuscript for intellectual content, study supervision

130 Bart Staels: data acquisition, critical revision of the manuscript for intellectual content, study

131 supervision

132

133 
134

135

136

137

138

139

140

141

142

143

144

145

146

147

148

149

150

151

152

153

154

155

156 157

\section{ABSTRACT}

Background and aims: Peroxisome proliferator-activated receptors (PPARs) have been implicated in NASH pathogenesis, mainly based on animal data. Gene expression data in NASH patients are scarce. We studied liver PPAR $\alpha, \beta / \delta$ and $\gamma$ expression in a large cohort of obese patients assessed for presence of NAFLD at baseline and 1 year follow-up. Methods: Patients presenting to the obesity clinic underwent a hepatic work-up. If NAFLD was suspected, liver biopsy was performed. Gene expression was studied by mRNA quantification. Patients were reassessed after 1 year. Results: 125 patients were consecutively included with follow-up including liver biopsy in $n=85$. Liver PPAR $\alpha$ expression negatively correlated with presence of NASH $(p=0.001)$ and with severity of steatosis $(p=0.003)$, ballooning $(p=0.001)$, NASH activity score $(\mathrm{p}=0.008)$ and fibrosis $(\mathrm{p}=0.003)$. PPAR $\alpha$ expression was positively correlated to adiponectin $\left(\mathrm{R}^{2}=0.345, \mathrm{p}=0.010\right)$ and inversely correlated to visceral fat $\left(\mathrm{R}^{2}=-\right.$ 0.343, $\mathrm{p}<0.001)$, HOMA IR $\left(\mathrm{R}^{2}=-0.411, \mathrm{p}<0.001\right)$ and $\mathrm{CK} 18\left(\mathrm{R}^{2}=-0.233, \mathrm{p}=0.012\right)$. Liver PPAR $\beta / \delta$ and PPAR $\gamma$ expression did not correlate with any histological feature nor with glucose metabolism or serum lipids. At 1 year, correlation of PPAR $\alpha$ expression with liver histology was confirmed. In longitudinal analysis, an increase in expression of PPAR $\alpha$ and its target genes was significantly associated with histological improvement $(\mathrm{p}=0.008)$. Conclusion: Human liver PPAR $\alpha$ gene expression negatively correlates with NASH severity, visceral adiposity and insulin resistance and positively with adiponectin. Histological improvement is associated with an increase in expression of PPAR $\alpha$ and its target genes. These data might suggest that PPAR $\alpha$ is a potential therapeutic target in NASH. 
158

159

160 Non-alcoholic fatty liver disease (NAFLD), the hallmark of which is the accumulation of fat 161

178 PPARs belong to the nuclear receptor superfamily[6]. After binding to their ligands, PPARs

179 form heterodimers with retinoid $\mathrm{X}$ receptors and these heterodimers regulate transcription of

\section{INTRODUCTION}

in the liver in the absence of alcohol consumption or other causes of secondary steatosis, is highly prevalent in Western societies. Non-alcoholic steatohepatitis (NASH), the subtype of NAFLD where steatosis is accompanied by inflammation and hepatocellular damage, is increasingly recognized as an important cause of liver and non-liver-related morbidity and mortality with an increasing impact on health-care resources[1,2].

The pathophysiology of NAFLD remains, however, largely unknown. Based mainly on epidemiological data, NAFLD and NASH are intimately linked to visceral adiposity, insulin resistance and diabetes, and the metabolic syndrome[2].

As insulin resistance and fatty acid metabolism have shown to impact on NAFLD, drugs targeting glucose or lipid metabolism have been evaluated for NASH treatment[3]. Several molecules targeting hepatic metabolic processes are currently under investigation. The most promising clinical results were up to now obtained with the thiazolidinediones, which are peroxisome proliferator-activated receptor (PPAR) gamma agonists[4]. Recently, hepatoprotective effects of a dual PPAR $\alpha / \delta$ agonist were reported in rodent NASH-models[5]. various target genes[6]. PPAR $\alpha$ is expressed in metabolically active tissues and regulates genes involved in fatty acid $\beta$-oxidation, although it also impacts on gluconeogenesis and inflammatory responses[7]. PPAR $\beta / \delta$ also seems to be an important metabolic regulator, 
183 which may also act on Kupffer cells to modulate NASH[8]. PPAR $\gamma$ is predominantly

184 expressed in adipose tissue, where it controls adipocyte differentiation, but to a lesser extent

185 also in the liver. PPAR $\gamma$ activation improves insulin sensitivity and glucose homeostasis[9].

186

187 Although numerous data on the role of altered expression of PPARs in the development of

188 NAFLD and NASH in preclinical animal models are available, comparable human data are 189 scarce[6, 10-12].

190

191 The aim of our study was to analyse the liver tissue gene expression pattern of the PPARs in

192 relation to the histological severity of NAFLD and to analyse longitudinally the relation 193 between the changes in PPAR expression and in liver histology in drug-naive overweight 194 individuals.

195 


\section{PATIENTS AND METHODS}

197

\section{$198 \quad$ Metabolic work-up}

199 Patients visiting the obesity clinic of the Antwerp University Hospital (a tertiary referral 200 facility) for a problem of overweight $\left(B M I \geq 25-29.9 \mathrm{~kg} / \mathrm{m}^{2}\right)$ or obesity $\left(\mathrm{BMI} \geq 30 \mathrm{~kg} / \mathrm{m}^{2}\right)$ were 201 prospectively recruited. They underwent a metabolic and a liver-specific program as 202 previously reported[13] (see supplementary materials, suppl.).

204 Patients were excluded from further analysis in case of significant alcohol consumption (>20 $205 \mathrm{~g} /$ day), history of bariatric surgery, diagnosis of another liver disease, pre-existing diabetes 206 (as diabetics constitute a specific risk group for NAFLD and anti-diabetic treatments (diet, 207 drugs) were considered potential confounders) or treatment by fibrates (that have PPAR208 agonistic properties). Patients who were, however, diagnosed with de novo diabetes at 209 baseline or at follow-up were not excluded.

211 Suspicion of NAFLD was defined by abnormal liver tests [aspartate aminotransferase (AST) 212 and/or alanine aminotransferase (ALT) and/or gamma glutamyl transpeptidase (GGT) and/or 213 alkaline phosphatase (ALP)] and/or liver ultrasound abnormality [steatotic liver (Ultrasound 214 steatosis score (USS) $\geq 1)]$.

215

216 Liver biopsy

217 When one or more of these criteria were met, a liver biopsy was proposed, as this is still the 218 gold standard to accurately diagnose the different NAFLD subtypes and severity and reliable 219 non-invasive tools are insufficiently validated in this specific population. This protocol is part 
220

221

222

223 For patients going to bariatric surgery, a liver biopsy was proposed regardless of the criteria. 224 225 226

of the HEPADIP protocol (Belgian registration number B30020071389) that was approved by the Ethics Committee of the Antwerp University Hospital (reference 6/25/125).

Liver biopsy was performed (after additional informed consent) percutaneously (16G Menghini) or peri-operatively (14G Tru-Cut).

Haematoxylin-eosin stain, Sirius red stain, reticulin stain and Perls' iron stain were routinely performed on all biopsies and analyzed by two experienced pathologists blinded for any clinical data. The different histological features of NAFLD were assessed using the NASH Clinical Research Network (NASH CRN) Scoring System[14].

The presence of NASH was defined according to Chalasani et al necessitating the combined presence of some degree of steatosis, some degree of ballooning and some degree of lobular inflammation[15]. We also looked at the NAFLD Activity Score (NAS)-based distribution of no NASH $(\mathrm{NAS}<3)$, borderline or probable NASH (NAS=3 or 4) or definite NASH (NAS $\geq 5$ ) to make a subclassification of the overall population.

\section{RNA extraction and Real Time Quantitative PCR}

RNA was isolated from human liver by guanidinium thiocyanate/phenol/chloroform extraction. Reverse transcription was performed using the High Capacity Reverse Transcription kit (Applied Biosystems, Life Technologies, Carlsbad,USA). PCR was performed with Brilliant II SYBR Green QPCR Master Mix (Agilent Technologies,Santa Clara,USA) on a Stratagene Mx3005P system (Agilent Technologies) using specific primers. mRNA levels were subsequently normalized to those of cyclophilin and relative changes in 
245 gene expression were then determined using the $2^{-\Delta \Delta \mathrm{Ct}}$ method using normal livers (NAS $=0$ 246 and no fibrosis) as the reference population set to $1 . \Delta \mathrm{C}_{\mathrm{t}}$ refers to the cycle number at which 247 the transcripts were detectable $\left(\mathrm{C}_{\mathrm{t}}\right)$ normalized to the cycle number of cyclophilin. To assess 248 whether the observed changes in PPAR $\alpha$ expression were functionally relevant, gene 249 expression of well-characterized liver PPAR $\alpha$ target genes was studied by RNA array as 250 previously described[16].

251 
252

253 Following their baseline assessment, patients preferentially entered a weight management 254 255 256

\section{Follow-up} program with emphasis on life style modification and without prescription of specific antiobesity drugs. Patients who met the reimbursement criteria for bariatric surgery in Belgium $\left(\mathrm{BMI} \geq 40 \mathrm{~kg} / \mathrm{m}^{2}\right.$ or $\mathrm{BMI} \geq 35 \mathrm{~kg} / \mathrm{m}^{2}+$ comorbidity) and who had a positive evaluation by the multidisciplinary team of the obesity clinic (our centre is an European Association for the Study of Obesity-accreditated Collaborating Centre for Obesity Management) could ask for bariatric surgery. After 1 year of follow-up, the baseline assessment was repeated in all patients, including liver biopsy if the patient consented. This protocol is part of the HEPADIP protocol (Belgian registration number B30020071389) that was approved by the Ethics Committee of the Antwerp University Hospital (reference 6/25/125).

\section{$\underline{\text { Statistical analysis }}$}

Values were expressed as mean \pm standard deviation (SD) whenever applicable. The results were analyzed with an independent samples t-test (normally distributed continuous variables), Mann Whitney U test or Kruskall-Wallis test (non-normally distributed continuous variables, categorical variables, scores) and Chi square test (prevalences) for the comparison of different groups. As most of the parameters were not normally distributed, Spearman rank correlations were calculated for the continuous variables. Binary or linear logistic regression was used to establish the relationship with categorical variables. Univariate linear regression was performed to identify factors independently predicting HOMA IR. Factors were reported by the adjusted coefficient of determination $\left(\mathrm{R}^{2}\right)$ and the significance (p-value). All variables significantly associated with HOMA IR in univariate linear regression analysis were included in multivariate forward conditional analyses to identify variables that where independently associated. Baseline and follow-up data were compared using paired samples t-test, Wilcoxon 
277 signed rank test or McNemar test (dichotomous variables) as appropriate. Calculations were 278 made using SPSS 18.0 for Windows. A p value <0.05 was considered statistically significant.

279 
RESULTS

\section{Main characteristics}

283 Between October 2005 and October 2008, 245 patients were screened. Seven patients were 284 excluded from further analysis because of the discovery of a formerly unknown chronic liver 285 disease (1 primary biliary cirrhosis, 1 haemochromatosis, 1 chronic hepatitis C, 2 chronic 286 hepatitis B) or because of alcohol consumption disclosed upon repeated interrogation (2 287 patients). From the remaining 238 patients, $47(19.7 \%)$ had none of the criteria to propose a 288 liver biopsy. In the other 191 patients at least one criterion was met. Liver biopsy was 289 performed in $128 / 191$ of those patients $(67.0 \%$, or $52.2 \%$ of the overall cohort of 245 290 patients). None of these patients were taking antidiabetic drugs; 28 were on statin treatment; 3 291 were on fibrates and excluded from further analysis. Gene expression studies were performed 292 on spare frozen liver tissue samples of the 125 remaining patients. Their main characteristics 293 are listed in Table 1.

294

295 Histology

296 Thirty-seven (29.6\%) biopsies were performed during bariatric surgery. Mean biopsy length 297 for lightmicroscopic evaluation was 17.2 $\pm 7.9 \mathrm{~mm}$ (range 9-45) and the mean number of portal 298 tracts was 8.7 \pm 2.9 (range 4-20). The most important histological features are listed in Table 2 . 299

300 Gene expression and correlation with histology

301 Expression of PPAR $\alpha$ decreased significantly with increasing grade of steatosis $(\mathrm{p}=0.003)$, 302 the score for ballooning $(\mathrm{p}=0.001)$, the presence of NASH $(\mathrm{p}=0.001)$ (Fig. 1A), the NAS303 based classification of no NASH/borderline NASH/definite NASH ( $=0.002)$, the NAS $304(\mathrm{p}=0.008)$ (Fig. 1B), as well as with fibrosis $(\mathrm{p}=0.003)$ (Fig. 1C) (Chi Square or Kruskal 
305 Wallis non-parametric testing). PPAR $\alpha$ expression was consistently lower with increasing

306 severity for each parameter. PPAR $\alpha$ expression also tended to be lower with increasing 307 inflammation $(\mathrm{p}=0.084)$.

309 No significant correlations were found between PPAR $\beta / \delta$ or PPAR $\gamma$ expression and any of 310 the histological features.

312 Gene expression and correlation with anthropometrical, biochemical and metabolic

\section{3 parameters}

314 The anthropometrical, biochemical and metabolic parameters that significantly correlated 315 with PPAR gene expression levels are listed in Table 3.

316

\section{Predictors of HOMA IR}

318 Insulin resistance is one of the key components of the metabolic syndrome. Factors that 319 significantly correlate with HOMA IR in a univariate and multivariate analysis are listed in 320 Suppl. Table 1 (Suppl.). In a multivariate analysis, PPAR $\alpha$ expression remains an 321 independent and negative predictor of HOMA IR, even if histological parameters are included. 322 PPAR $\alpha$ expression, waist and NAS have a global $\mathrm{R}^{2}$ of 0.391 for the prediction of HOMA IR.

\section{$324 \quad$ Follow-up}

325 A complete follow-up dataset including liver biopsy was available in 85 patients, 50/80 $326(58.8 \%)$ had a weight management programme. Their main characteristics are listed in Table 327 1. In comparison to baseline, there is a significant improvement in anthropometric parameters, 328 serum lipids, parameters of glucose metabolism and liver enzymes (Table 1). 
330 Mean length of follow-up biopsy was 22.1 $18.2 \mathrm{~mm}$ (range 12-42) and the mean number of

331 portal tracts was 9.8 \pm 5.8 (range 4-24). The histological lesions are summarized in Table 2. In

332 comparison to baseline, all histological parameters overall improved, including fibrosis.

333 Although overall fibrosis regressed, a few patients showed fibrosis progression and 3 334 developed cirrhosis.

336 In a cross-sectional analysis on the 1-year follow-up biopsies, PPAR $\beta / \delta$ and PPAR $\gamma$ didn't 337 correlate with histology. By contrast, expression of PPAR $\alpha$ was significantly different 338 according to the grade of steatosis $(\mathrm{p}=0.015)$, of inflammation $(\mathrm{p}=0.017)$, of ballooning $339(\mathrm{p}=0.005)$, the presence of NASH $(\mathrm{p}=0.015)$, the NAS-based classification of no $340 \mathrm{NASH} / \mathrm{borderline} \mathrm{NASH/definite} \mathrm{NASH}(\mathrm{p}=0.005)$ and the NAS $(\mathrm{p}=0.030)$, reproducing the 341 results of the cross-sectional analysis at baseline (Chi Square or Kruskal Wallis non342 parametric testing). In contrast to baseline, there was no significant correlation of PPAR $\alpha$ 343 expression with fibrosis $(\mathrm{p}=0.321)$. PPAR $\alpha$ expression was consistently lower with increasing 344 severity for each parameter.

346 Overall PPAR $\alpha$ expression significantly improved from $0.321 \pm 0.209$ at baseline to $3470.514 \pm 0.209(\mathrm{p}<0.001$, paired samples Wilcoxon signed ranks test) (Fig. 2). In the 24/34 348 patients with NASH at baseline who did not have NASH at 1 year follow-up, PPAR $\alpha$ 349 expression highly significantly increased from $0.280 \pm 0.072$ to $0.527 \pm 0.165$ ( $\mathrm{p}=0.004)$, 350 whereas in the 10/34 who maintained the diagnosis of NASH PPAR $\alpha$ expression was 351 unchanged (0.384 \pm 0.138 vs. $0.392 \pm 0.143$, p=0.983) (Fig. 3 and Suppl. Fig. 1).

353 As it was technically unfeasible to measure liver PPAR $\alpha$ protein levels due to the lack of 354 additional spare biopsy samples in the non-bariatric surgery patients and due to the 
355 notoriously low quality of the available antibodies, the expression of well-known peroxisome

356 proliferator response element (PPRE)-driven liver PPAR $\alpha$ target genes was measured as an 357 estimate of changes in PPAR $\alpha$ activity. Carnitine palmitoyl transferase 1 liver isoform 358 (CPT1A)[17], fibroblast growth factor 21 (FGF21)[18] and pyruvate dehydrogenase kinase 359 isoenzyme 4 (PDK4) expression all significantly increased in parallel with PPAR $\alpha$ in the $36024 / 34$ patients with NASH at baseline and no more NASH at 1 year, whereas their expression 361 was unchanged in the 10/34 patients who maintained the diagnosis of NASH at 1 year (Fig. 3 362 and Suppl. Fig. 1). The evolution of several other genes related to metabolism and 363 inflammation are shown in Fig. 3. The upregulation of PPAR $\alpha$ and its target genes in patients 364 with NASH at baseline but with resolution of NASH at 1 year follow-up was paralleled by a 365 significant downregulation of inflammatory response genes as well as a number of genes 366 involved in lipogenesis and lipid-droplet formation (Fig. 3).

368 In table 4 baseline and follow-up data are presented separately for the patients with a weight 369 management program and the patients who underwent bariatric surgery. Although changes are 370 more marked in the bariatric surgery group, overall results are comparable, with a significant 371 improvement in PPAR $\alpha$ expression and liver histology also when analysis is restricted to the 372 weight management group.

373

374 The parameters that were associated with a decrease in NAS in univariate and multivariate 375 analysis are listed in Suppl. Table 2 (Suppl.). The change in PPAR $\alpha$ was related significantly 376 to the decrease in NAS in univariate but not multivariate analysis. 
378

379

380 Whereas several studies in animal models are available on metabolic pathways implicated in 381

\section{DISCUSSION} the pathogenesis of NASH, data on altered expression of genes involved in lipid and glucose metabolism in human liver tissue in NASH are scarce. We report on gene expression of the PPARs in human liver tissue at baseline and at 1 year of follow-up in a large series of patients with a wide range of histological severity of NAFLD. We show that the gene expression of PPAR $\alpha$ is significantly lower with increasing severity of NASH, whereas the expression of the other PPARs is unaltered. In cross-sectional analysis at 1 year of follow-up, the inverse correlation between PPAR $\alpha$ expression and histological severity of NASH was confirmed. In longitudinal analysis increase in expression of PPAR $\alpha$ and its target genes was associated with histological improvement. This offers a rationale for drugs targeting PPAR $\alpha$ in the treatment of NASH.

Before discussing the results, it should be emphasized that human studies on NAFLD are hampered by various methodological issues. Liver biopsy is still the gold standard for accurate assessment of NAFLD and NASH, but remains an invasive procedure, limiting the number of included patients as well as the availability of spare liver samples for additional analysis[19]. Most NASH studies are retrospective. Patients are mostly highly selected, as they are referred to specialized hepatology clinics because of elevated transaminases or, in case of bariatric surgery series, only represent one extreme of the spectrum. This results in patient series with relative high prevalence of more advanced disease. In some studies results are compared with a matched control group, the selection of which is also subject to bias and in which histological data are usually lacking. 
403 The two-step approach of our study aimed at overcoming some of these methodological 404 issues. In a first step, all patients presenting to the obesity clinic were assessed, regardless of 405 any a priori suspicion of liver disease. They underwent a series of tests aiming at detecting 406 any sign of liver disease and if there was, a liver biopsy was proposed, representing the 407 second step. We estimate that this two-step prospective approach avoids some mechanisms of 408 bias and allows confidently applying the obtained results to the overall population of 409 overweight patients. Furthermore this approach resulted in a patient series containing the 410 whole NAFLD spectrum (which is by the design of the study inevitably different from the 411 patient population seen at our hepatology clinics). The patients who ultimately appeared to 412 have a normal liver histology were used as an internal control group, avoiding the need for an 413 external group of matched controls[20].

416 In our study, which is to our knowledge the first to report on PPAR gene expression in a large 417 cohort of well-documented NAFLD patients, PPAR $\alpha$ expression was clearly decreased when 418 steatosis and steatohepatitis become more severe. As we are directly assessing the tissue 419 expression of the gene, these data provide strong evidence for the intimate link between 420 PPAR $\alpha$ expression and NASH severity.

422 In the majority of the patients, a one year follow-up biopsy was available. Outside the setting 423 of bariatric surgery or clinical trials, series with paired liver biopsies in NAFLD patients are 424 rare. The largest series to date looking at the effects of lifestyle modification on liver 425 histology in NASH by Promrat et al included 28 patients with paired biopsies[21]. In our 426 series, 50 non-surgical patients were histologically re-evaluated after 1 year, making it the 427 largest reported series in this setting. The beneficial effect of life style modification on liver 
428

429

430

431

432

433

434

435

436

437

440

histology could be confirmed, with loss of NASH diagnosis in about $30 \%$ of cases, in relation with loss of weight and waist circumference and improvement of insulin sensitivity.

The follow-up assessment of the patients first allowed for a second cross-sectional analysis, which confirmed the inverse correlation between PPAR $\alpha$ expression and histological severity of NASH. Furthermore, longitudinal analysis convincingly showed that histological improvement is strongly associated with an increase in PPAR $\alpha$ expression. As the changes were significant both in the non-bariatric as in the bariatric surgery group (although more pronounced in the latter, in relation to the more pronounced improvement in weight and metabolic parameters), the effect on PPAR $\alpha$ expression could not be attributed to a specific metabolic effect of bariatric surgery.

The close association between PPAR $\alpha$ expression and NASH severity both in cross-sectional analysis and in follow-up can, however, not resolve the issue of causality. A relevant endpoint in the treatment of NASH-patients is the loss of the diagnosis of NASH, as this is the subtype at risk for progressive liver disease[22, 23]. Of the patients with the diagnosis of $\mathrm{NASH}$ at baseline, those who had no more NASH at follow-up had a significant increase in PPAR $\alpha$ expression, whereas those who did not resolve their NASH also had no improvement in PPAR $\alpha$ expression, further supporting the link between PPAR $\alpha$ expression and NASH severity.

We did not study the protein expression, which was technically unfeasible due to the limited size of the spare biopsy sample (that was mostly entirely used for RNA extraction) and the notoriously low quality of the existing commercial antibodies. Therefore, to further assess the functional relevance of the changes in PPAR $\alpha$ expression, we also studied the expression of 
453 CPT1A, FGF21 and PDK4, well-known PPRE-driven PPAR $\alpha$ target genes[17, 18]. This

454 approach is relevant since previous studies in animal models revealed gene-dosage effects of 455 PPAR $\alpha$ gene expression on target gene regulation and function[24]. The expression of these 456 target genes parallels the changes in $\operatorname{PPAR} \alpha$, and they increase in relation with NASH 457 disappearance, whereas NASH persists in association with unchanged expression of these 458 target genes. These data support the functional relevance of the observed changes in PPAR $\alpha$ 459 gene expression.

461 Nevertheless the possibility that the observed changes in PPAR $\alpha$ expression are secondary to 462 the improvement in histology cannot be excluded by the current study design. Our data are, 463 however, in line with convincing animal data that show a beneficial role for PPAR $\alpha$ in NASH 464 both in prevention and treatment[5]. These studies, including PPAR $\alpha$ knock-out models and 465 the use of several PPAR $\alpha$ agonist, provide evidence that PPAR $\alpha$ is protective against NASH 466 and that modulation of its expression can improve liver histology, supporting the hypothesis 467 that the observed improvement in our study is at least in part mediated by increased PPAR $\alpha$ 468 expression[10, 12, 25]. Few clinical pilot studies were performed to assess the impact of 469 fibrates, which are PPAR $\alpha$ agonists, on the evolution of NASH with conflicting results[2629]. Preliminary results of GFT505, a dual PPAR $\alpha$ and $\beta / \delta$ agonist with hepatotrophic activity, on parameters of glucose metabolism and on liver enzymes are prompting further research[30].

475 Interestingly, PPAR $\alpha$ expression also correlates with parameters of glucose metabolism, 476 adiponectin levels and visceral fat accumulation. The link between increased visceral fat 477 accumulation, decreased adiponectin levels, increased insulin resistance (and impaired 
478 glucose metabolism) and more severe NASH is well established [2, 31]. Adiponectin is 479 protective against NASH, whereas insulin resistance is deleterious. This is also in line with 480 recent data on the regulatory effect of adiponectin on hepatic PPAR $\alpha$ expression and activity 481 [9]. Our study shows that all these alterations are in parallel with a reduced PPAR $\alpha$ 482 expression in the liver and further support the hypothesis that reduced PPAR $\alpha$ expression is a 483 key phenomenon in progressing NASH.

Other PPARs have also been implicated in the pathogenesis and treatment of NASH. PPAR $\gamma$ regulated genes stimulate adipogenesis and lipid uptake by fat cells and regulate fatty acid storage and glucose metabolism[6]. [32]. PPAR $\gamma$ is most abundantly expressed in adipose tissue[6]. Several animal studies show a beneficial role of PPAR $\gamma$ in NASH[33].

492 Little data exist on PPAR $\gamma$ expression in human NAFLD. Pettinelli et al reported PPAR $\gamma$ 493 expression in 22 patients who underwent bariatric surgery (compared to 16 cholecystectomy 494 controls) and found the highest expression in those with steatohepatitis[34]. The latter, 495 however, represented only 6 patients. Lima-Cabello et al reported on 43 NAFLD patients 496 compared to 44 hepatitis $\mathrm{C}$ and 22 cholecystectomy controls, showing higher levels in 497 steatosis and NASH compared to controls, but PPAR $\gamma$ expression was not different 498 comparing simple steatosis with NASH[35].

500 In our study PPAR $\gamma$ expression was not altered in relation to the presence or severity of 501 NAFLD, leading to the hypothesis that the observed effect of glitazones on liver fat and 502 inflammation[36] is mostly secondary to the improvement in extrahepatic metabolic features 
503 and adiponectin, and not by a primary hepatic effect. This is also in line with the limited

504 expression of PPAR $\gamma$ in the liver in comparison with adipose tissue[6]. It is also interesting to

505 note that in our study liver PPAR $\gamma$ gene expression was not correlated to parameters of 506 glucose metabolism or serum lipids, again suggesting that the direct effects of PPAR $\gamma$ agonist 507 are predominantly extrahepatic. This might also explain why no further improvement in liver 508 histology is observed beyond one year of treatment, although metabolic parameters further 509 improve[37]. Finally, the number of patients included, the prospective assessment of the 510 patients and the presence of the whole range of the NAFLD spectrum quite evenly distributed 511 (allowing to compose a control group of patients with normal liver histology within the study 512 population) are strengths of our study design and might explain why previous reports on 513 enhanced PPAR $\gamma$ expression in human NAFLD samples could not be reproduced.

515 Finally we could not demonstrate a relation between PPAR $\beta / \delta$ and NAFLD severity. Recent 516 experimental data point towards a role for Kupffer cell PPAR $\beta / \delta$ in NAFLD[38]. It might be 517 that changes in Kupffer cell PPAR $\beta / \delta$ could not be detected by the methods we used due to 518 the low contribution of Kupffer cell to the overall hepatic mRNA pool, to which parenchymal 519 cells mainly contribute.

521 In conclusion, in line with experimental data on the role of PPAR $\alpha$ in the pathogenesis of $522 \mathrm{NASH}$, we demonstrated that liver PPAR $\alpha$ expression decreases with progressing histological 523 severity of NAFLD and increases in association with NASH improvement, whereas the 524 expression of the other PPARs remain unaltered. 
526

527

528

529

530

531

532

533

534

535

536

537

$538 \quad$ Fig. 3.

539

540

541

542

543

544

\section{LEGEND TO THE FIGURES}

Fig. 1. PPARa expression. Bar chart showing the relative PPAR $\alpha$ expression compared to normal liver tissue between patients without and with NASH (1A), in relation to the NAS (1B) and in relation to stage of fibrosis (1C). PPAR $\alpha=$ peroxisome proliferator-activated receptor alpha; NAS = non-alcoholic fatty liver disease activity score; $\mathrm{n}=$ number of patients; $*=$ significant difference with $\mathrm{p}<0.05$.

Fig. 2. PPAR 2 expression at baseline and follow-up. Bar chart showing the relative PPAR $\alpha$ expression compared to normal liver tissue at baseline and follow-up in the 85 patients with paired liver biopsies. PPAR $\alpha=$ peroxisome proliferatoractivated receptor alpha; $*$ significant difference with $\mathrm{p}<0.05$.

Changes in gene expression between baseline and follow-up of PPARa, PPAR $\alpha$ target genes and related genes involved in fatty acid uptake, metabolism and inflammation in NASH patients with resolution of NASH on follow-up. Significant upregulation upon follow-up is marked in green, downregulation is marked in red. * significant with $\mathrm{p}<0.05$; ** significant with $\mathrm{p}<0.01 ; \mathrm{NC}=$ no change. 
545

546

547

548

549

550

551

552

553

554

555

556

557

558

559

560

561

562

563

564

565

\section{REFERENCES}

[1] Vernon G, Baranova A, Younossi ZM. Systematic review: the epidemiology and natural history of non-alcoholic fatty liver disease and non-alcoholic steatohepatitis in adults. Aliment Pharmacol Ther 2011;34:274-285.

[2] Vanni E, Bugianesi E, Kotronen A, De Minicis S, Yki-Jarvinen H, Svegliati-Baroni G. From the metabolic syndrome to NAFLD or vice versa? Dig Liver Dis 2010;42:320330.

[3] Lonardo A, Bellentani S, Ratziu V, Loria P. Insulin resistance in nonalcoholic steatohepatitis: necessary but not sufficient - death of a dogma from analysis of therapeutic studies? Expert Rev Gastroenterol Hepatol 2011;5:279-289.

[4] Pais R, Moraru I, Ratziu V. Glitazones for human nonalcoholic steatohepatitis. Therap Adv Gastroenterol 2011;4:325-334.

[5] Staels B, Rubenstrunk A, Noel B, Rigou G, Delataille P, Millatt LJ, et al. Hepatoprotective effects of the dual PPARalpha/delta agonist GFT505 in rodent models of NAFLD/NASH. Hepatology 2013; 58: 1941-1952.

[6] Tailleux A, Wouters K, Staels B. Roles of PPARs in NAFLD: Potential therapeutic targets. Biochim Biophys Acta 2012; 5: 809-818.

[7] Lefebvre P, Chinetti G, Fruchart JC, Staels B. Sorting out the roles of PPAR alpha in energy metabolism and vascular homeostasis. J Clin Invest 2006;116:571-580.

[8] Shan W, Palkar PS, Murray IA, McDevitt EI, Kennett MJ, Kang BH, et al. Ligand activation of peroxisome proliferator-activated receptor beta/delta (PPARbeta/delta) 
attenuates carbon tetrachloride hepatotoxicity by downregulating proinflammatory gene expression. Toxicol Sci 2008;105:418-428.

[9] Fievet C, Staels B. Efficacy of peroxisome proliferator-activated receptor agonists in diabetes and coronary artery disease. Curr Atheroscler Rep 2009;11:281-288.

570

571

572

573

574

575

576

577

578

579

580

581

582

584

585

586

587

[10] Ip E, Farrell GC, Robertson G, Hall P, Kirsch R, Leclercq I. Central role of PPARalpha-dependent hepatic lipid turnover in dietary steatohepatitis in mice. Hepatology 2003;38:123-132.

[11] Kallwitz ER, McLachlan A, Cotler SJ. Role of peroxisome proliferators-activated receptors in the pathogenesis and treatment of nonalcoholic fatty liver disease. World J Gastroenterol 2008;14:22-28.

[12] Ip E, Farrell G, Hall P, Robertson G, Leclercq I. Administration of the potent PPARalpha agonist, Wy-14,643, reverses nutritional fibrosis and steatohepatitis in mice. Hepatology 2004;39:1286-1296.

[13] Francque S, Verrijken A, Mertens I, Hubens G, Van Marck E, Pelckmans P, et al. Non-cirrhotic human NAFLD induces portal hypertension in relation to the histological degree of steatosis. Eur J Gastroenterol Hepatol 2010;22:1449-1457.

[14] Kleiner DE, Brunt EM, Van Natta M, Behling C, Contos MJ, Cummings OW, et al. Design and validation of a histological scoring system for nonalcoholic fatty liver disease. Hepatology 2005;41:1313-1321.

[15] Chalasani N, Younossi Z, Lavine JE, Diehl AM, Brunt EM, Cusi K, et al. The diagnosis and management of non-alcoholic fatty liver disease: Practice guideline by the American Association for the Study of Liver Diseases, American College of 
Gastroenterology, and the American Gastroenterological Association. Am J Gastroenterol 2012;107:811-826.

[16] Lefebvre B, Benomar Y, Guedin A, Langlois A, Hennuyer N, Dumont J, et al. Proteasomal degradation of retinoid $\mathrm{X}$ receptor alpha reprograms transcriptional activity of PPARgamma in obese mice and humans. J Clin Invest 2010;120:1454-1468.

[17] Song S, Attia RR, Connaughton S, Niesen MI, Ness GC, Elam MB, et al. Peroxisome proliferator activated receptor alpha (PPARalpha) and PPAR gamma coactivator (PGC-1alpha) induce carnitine palmitoyltransferase IA (CPT-1A) via independent gene elements. Mol Cell Endocrinol 2010;325:54-63.

[18] Inagaki T, Dutchak P, Zhao G, Ding X, Gautron L, Parameswara V, et al. Endocrine

[19] Brunt EM. Liver biopsy diagnosis of hepatitis: clues to clinically-meaningful reporting. regulation of the fasting response by PPARalpha-mediated induction of fibroblast growth factor 21. Cell Metab 2007;5:415-425.

602

[20] Francque SM, Verrijken A, Mertens I, Hubens G, Van Marck E, Pelckmans P, et al.

603 Noninvasive Assessment of Nonalcoholic Fatty Liver Disease in Obese or Overweight

604 Patients. Clin Gastroenterol Hepatol 2012. Randomized controlled trial testing the effects of weight loss on nonalcoholic steatohepatitis. Hepatology 2010;51:121-129. 
608 [22] Sanyal AJ, Brunt EM, Kleiner DE, Kowdley KV, Chalasani N, Lavine JE, et al. 609 Endpoints and clinical trial design for nonalcoholic steatohepatitis. Hepatology $610 \quad 2011 ; 54: 344-353$.

611 [23] Ratziu V, Bellentani S, Cortez-Pinto H, Day C, Marchesini G. A position statement on 612 NAFLD/NASH based on the EASL 2009 special conference. J Hepatol 2010;53:372$613 \quad 384$.

614 [24] Lalloyer F, Wouters K, Baron M, Caron S, Vallez E, Vanhoutte J, et al. Peroxisome 615 proliferator-activated receptor-alpha gene level differently affects lipid metabolism 616 and inflammation in apolipoprotein E2 knock-in mice. Arterioscler Thromb Vasc Biol $617 \quad 2011 ; 31: 1573-1579$.

618 [25] Larter CZ, Yeh MM, Van Rooyen DM, Brooling J, Ghatora K, Farrell GC. 619 Peroxisome proliferator-activated receptor-alpha agonist, Wy 14,643, improves 620 metabolic indices, steatosis and ballooning in diabetic mice with non-alcoholic 621 steatohepatitis. J Gastroenterol Hepatol 2012;27:341-350.

622 [26] Fernandez-Miranda C, Perez-Carreras M, Colina F, Lopez-Alonso G, Vargas C, Solis623 Herruzo JA. A pilot trial of fenofibrate for the treatment of non-alcoholic fatty liver 624 disease. Dig Liver Dis 2008;40:200-205.

625 [27] Nakamuta M, Morizono S, Soejima Y, Yoshizumi T, Aishima S, Takasugi S, et al. 626 Short-term intensive treatment for donors with hepatic steatosis in living-donor liver 627 transplantation. Transplantation 2005;80:608-612.

628 [28] Basaranoglu M, Acbay O, Sonsuz A. A controlled trial of gemfibrozil in the treatment 629 of patients with nonalcoholic steatohepatitis. J Hepatol 1999;31:384. 
630 [29] Laurin J, Lindor KD, Crippin JS, Gossard A, Gores GJ, Ludwig J, et al. 631 Ursodeoxycholic acid or clofibrate in the treatment of non-alcohol-induced 632 steatohepatitis: a pilot study. Hepatology 1996;23:1464-1467.

633 [30] Cariou B, Hanf R, Lambert-Porcheron S, Zair Y, Sauvinet V, Noel B, et al. Dual

634

635

636

637

638

640

641

642

643

644

645

646

647

648 Peroxisome Proliferator-Activated Receptor alpha/delta Agonist GFT505 Improves Hepatic and Peripheral Insulin Sensitivity in Abdominally Obese Subjects. Diabetes Care 2013; 36: 2923-2930.

[31] Verrijken A, Francque S, Mertens I, Talloen M, Peiffer F, Van Gaal L. Visceral adipose tissue and inflammation correlate with elevated liver tests in a cohort of overweight and obese patients. Int J Obes (Lond) 2010;34:899-907.

[32] Kanda T, Brown JD, Orasanu G, Vogel S, Gonzalez FJ, Sartoretto J, et al. PPARgamma in the endothelium regulates metabolic responses to high-fat diet in mice. J Clin Invest 2009;119:110-124.

[33] Rogue A, Spire C, Brun M, Claude N, Guillouzo A. Gene Expression Changes Induced by PPAR Gamma Agonists in Animal and Human Liver. PPAR Res 2010;2010:325183.

[34] Pettinelli P, Videla LA. Up-regulation of PPAR-gamma mRNA expression in the liver of obese patients: an additional reinforcing lipogenic mechanism to SREBP-1c induction. J Clin Endocrinol Metab 2011;96:1424-1430.

[35] Lima-Cabello E, Garcia-Mediavilla MV, Miquilena-Colina ME, Vargas-Castrillon J, Lozano-Rodriguez T, Fernandez-Bermejo M, et al. Enhanced expression of proinflammatory mediators and liver X-receptor-regulated lipogenic genes in nonalcoholic fatty liver disease and hepatitis C. Clin Sci (Lond) 2011;120:239-250. 
653 [36] Musso G, Gambino R, Cassader M, Pagano G. A meta-analysis of randomized trials 654 for the treatment of nonalcoholic fatty liver disease. Hepatology 2010;52:79-104.

655 [37] Ratziu V, Charlotte F, Bernhardt C, Giral P, Halbron M, Lenaour G, et al. Long-term 656 efficacy of rosiglitazone in nonalcoholic steatohepatitis: results of the fatty liver 657 improvement by rosiglitazone therapy (FLIRT 2) extension trial. Hepatology $658 \quad 2010 ; 51: 445-453$.

659 [38] Odegaard JI, Ricardo-Gonzalez RR, Red EA, Vats D, Morel CR, Goforth MH, et al. 660 Alternative M2 activation of Kupffer cells by PPARdelta ameliorates obesity-induced 661 insulin resistance. Cell Metab 2008;7:496-507.

662

663

664 


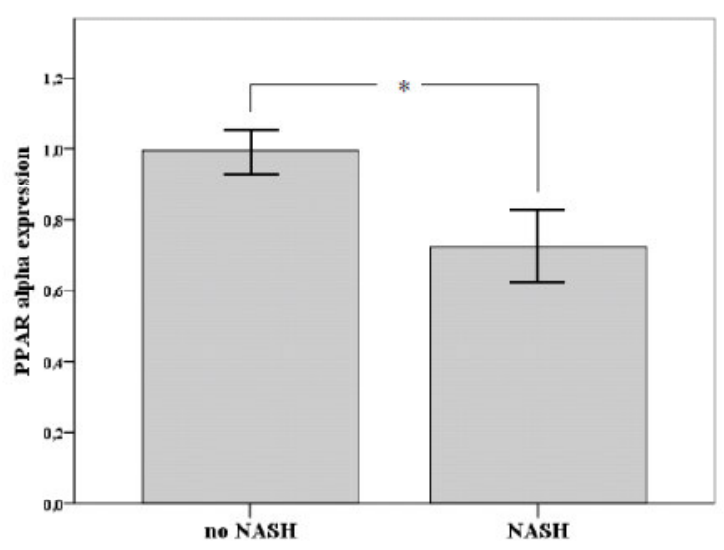

665

666
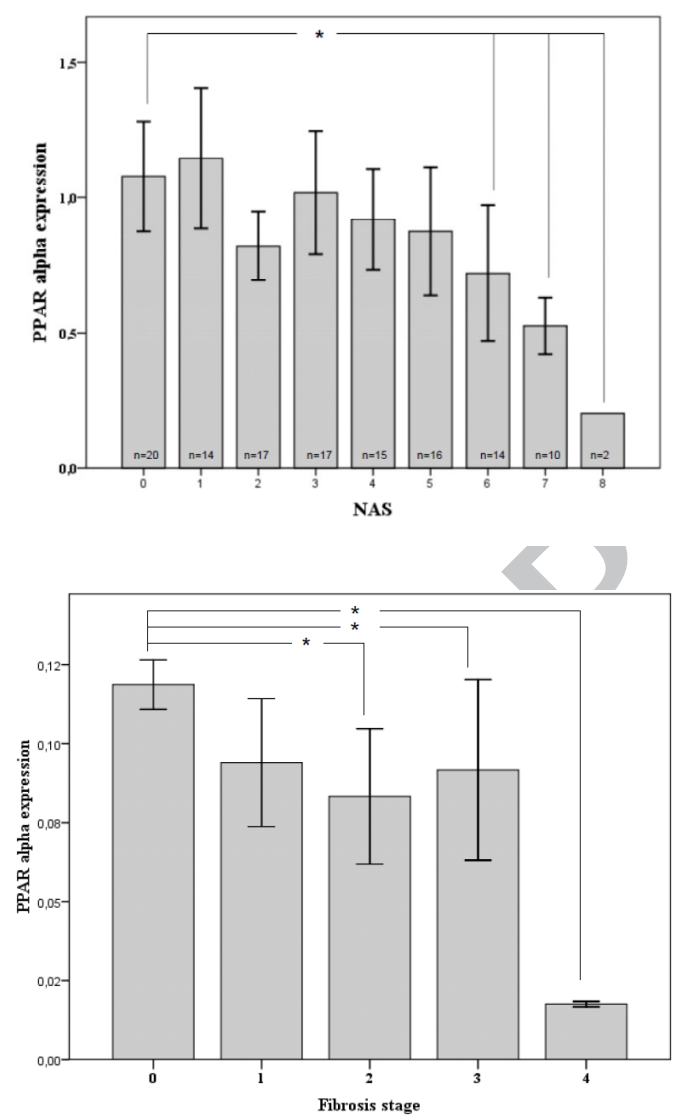

667

668 
669

670

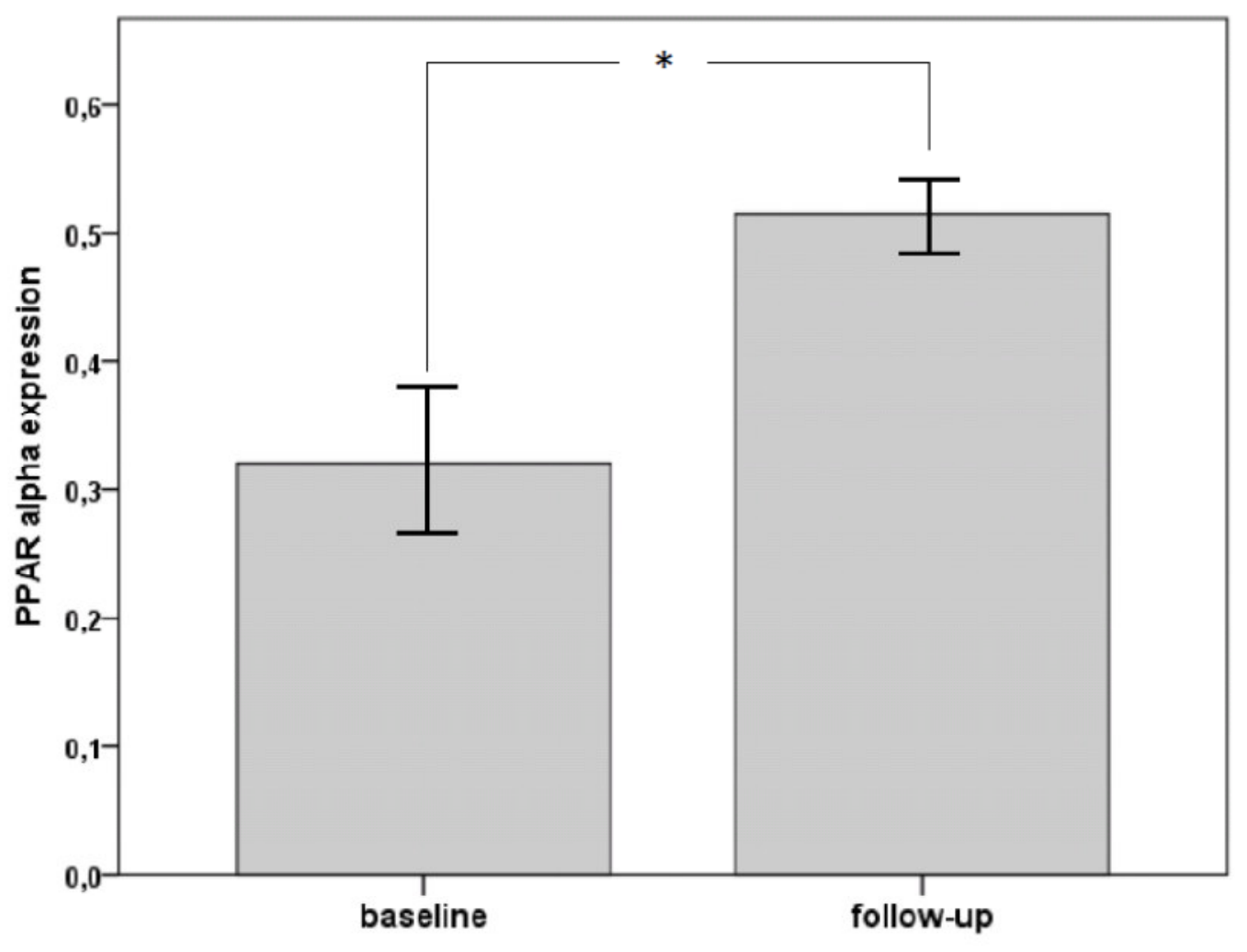

671

672 


\begin{tabular}{|c|c|c|c|}
\hline & Gene symbol & $\begin{array}{l}\text { NASH at baseline } \\
\text { no NASH at follow-up } \\
= \\
\text { responder }\end{array}$ & $\begin{array}{c}\text { NASH at baseline } \\
\text { NASH at follow-up } \\
= \\
\text { non-responder }\end{array}$ \\
\hline \multirow{4}{*}{ 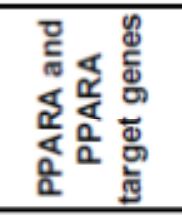 } & PPARA & $1.34^{*}$ & \begin{tabular}{|c|}
$\mathrm{NC}$ \\
\end{tabular} \\
\hline & CPT1A & $1.61^{*}$ & $\mathrm{NC}$ \\
\hline & FGF21 & $1.39^{*}$ & $\mathrm{NC}$ \\
\hline & PDK4 & $1.21^{*}$ & $\mathrm{NC}$ \\
\hline \multirow{3}{*}{ FA uptake } & CD36/FAT & $1.27^{*}$ & $\mathrm{NC}$ \\
\hline & FATP2 & $\mathrm{NC}$ & $\mathrm{NC}$ \\
\hline & FATP5 & $\mathrm{NC}$ & $\mathrm{NC}$ \\
\hline \multirow{12}{*}{ 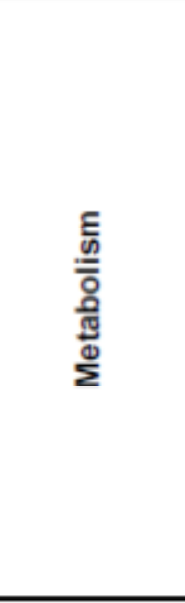 } & G6PC & $1.47^{*}$ & $\mathrm{NC}$ \\
\hline & $A C L$ & $\mathrm{NC}$ & $\mathrm{NC}$ \\
\hline & $A C C$ & $\mathrm{NC}$ & $\mathrm{NC}$ \\
\hline & FASN & $\mathrm{NC}$ & $1.95^{*}$ \\
\hline & $S C D 1$ & $1.28^{*}$ & $\mathrm{NC}$ \\
\hline & MOGAT1 & $1.48^{* *}$ & $\mathrm{NC}$ \\
\hline & DGAT2 & $\mathrm{NC}$ & $\mathrm{NC}$ \\
\hline & PLIN2 & $1.7^{*}$ & $\mathrm{NC}$ \\
\hline & LPIN2 & $1.49^{*}$ & $\mathrm{NC}$ \\
\hline & $L D L-R$ & $1.7^{*}$ & $\mathrm{NC}$ \\
\hline & PRKAA1 & $\mathrm{NC}$ & $\mathrm{NC}$ \\
\hline & PRKAB2 & $\mathrm{NC}$ & $\mathrm{NC}$ \\
\hline \multirow{10}{*}{ 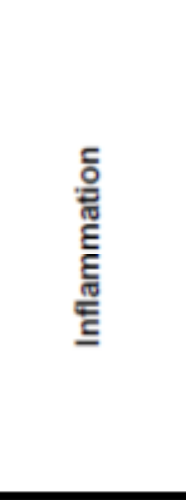 } & JUN & $2.53^{* *}$ & $\mathrm{NC}$ \\
\hline & JUND & $1.53^{* *}$ & $\mathrm{NC}$ \\
\hline & JUNB & $1.48^{*}$ & $\mathrm{NC}$ \\
\hline & FOS & $1.21^{*}$ & $\mathrm{NC}$ \\
\hline & REL & $1.21^{*}$ & $\mathrm{NC}$ \\
\hline & NFKBIA & $\mathrm{NC}$ & $\mathrm{NC}$ \\
\hline & TLR4 & $1.22^{*}$ & $\mathrm{NC}$ \\
\hline & GADD $45 B$ & $2.18^{*}$ & $\mathrm{NC}$ \\
\hline & $C R P$ & $3.68^{* *}$ & $\mathrm{NC}$ \\
\hline & SAA1 & $1.69^{\mathrm{x*}}$ & $\mathrm{NC}$ \\
\hline
\end{tabular}

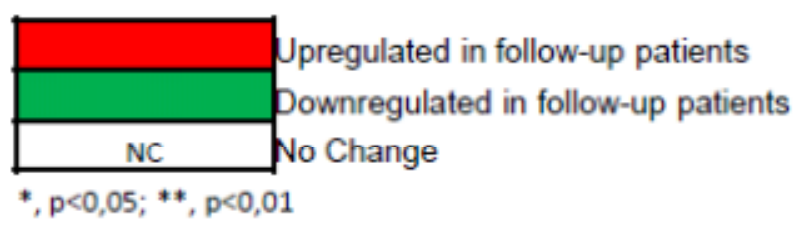

674

675 
676 Table 1. Main characteristics of the patient cohort at baseline $(n=125)$ and follow-up $(n$ $677=85)$.

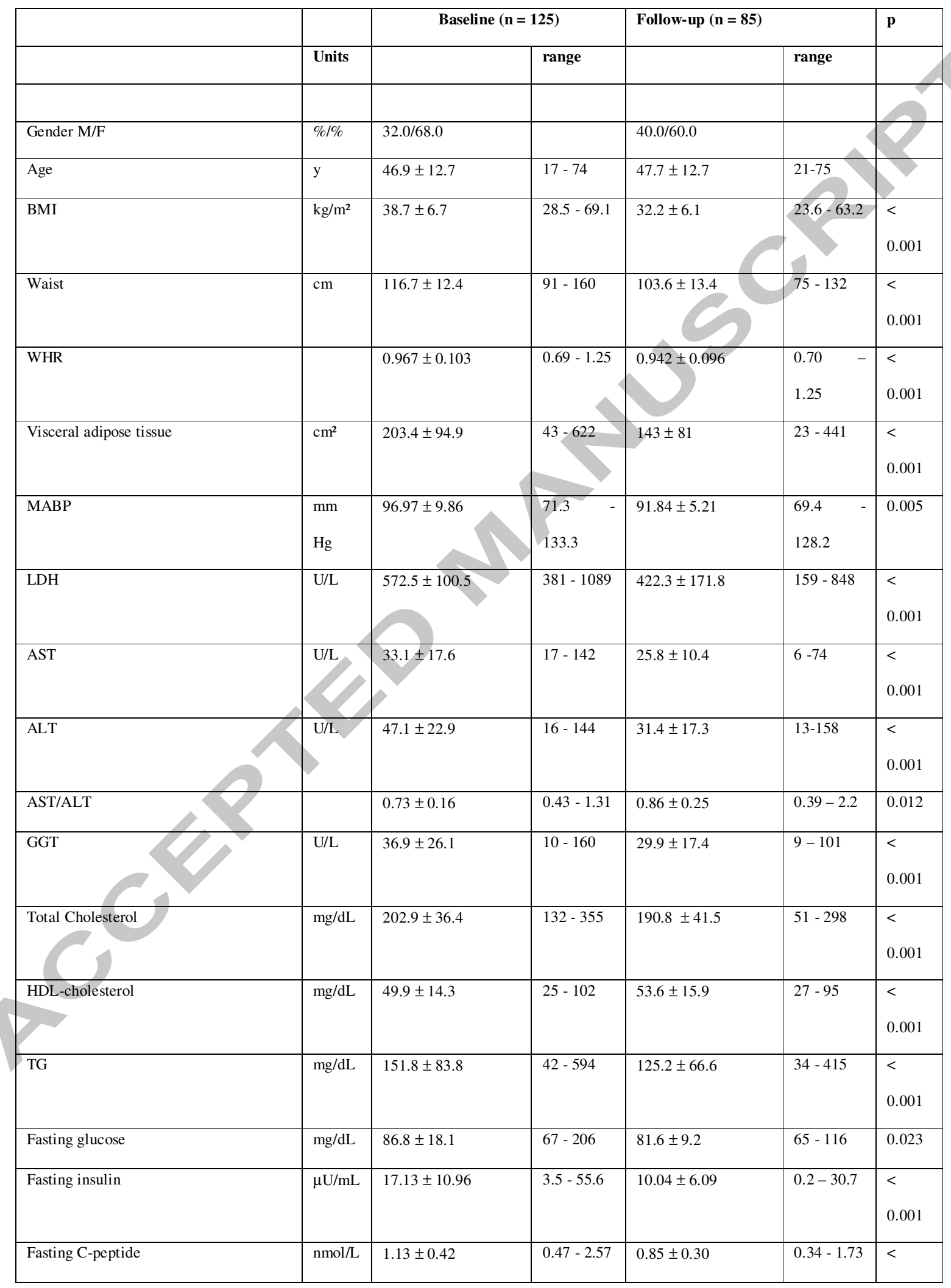




\begin{tabular}{|c|c|c|c|c|c|c|}
\hline & & & & & & 0.001 \\
\hline HBA1c & $\%$ & $5.67 \pm 0.61$ & $4.9-10.2$ & $5.43 \pm 0.39$ & $4.9-7.9$ & $\begin{array}{l}< \\
0.001\end{array}$ \\
\hline HOMA IR & & $3.84 \pm 3.12$ & $\begin{array}{ll}0.71 & - \\
20.33 & \end{array}$ & $2.06 \pm 1.40$ & $0.04-7.01$ & 0.021 \\
\hline USS & & $2.2 \pm 1.0$ & $0-3$ & $1.1 \pm 1.0$ & $0-3$ & $<+$ \\
\hline Diabetes absent/present & $\% / \%$ & $91.1 / 8.9$ & & $79.7 / 20.3$ & & $\mathrm{~ns}$ \\
\hline ABT peak excretion & $\%$ & $9.03 \pm 4.96$ & $0.7-34.4$ & $11.19 \pm 4.90$ & $2.1-23.1$ & $\begin{array}{l}< \\
0.001\end{array}$ \\
\hline ABT cumulative excretion & $\%$ & $12.84 \pm 6.60$ & $1.1-39.6$ & $16.51 \pm 6.81$ & $3.3-33.4$ & $\begin{array}{l}< \\
0.001\end{array}$ \\
\hline $\begin{array}{l}\text { Number criteria Metabolic Syndrome } \\
\text { NCEP ATP III }\end{array}$ & & $2.8 \pm 1.0$ & $0-5$ & $1.6 \pm 1.0$ & $0-4$ & $\begin{array}{l}< \\
0.001\end{array}$ \\
\hline $\begin{array}{l}\text { Number criteria Metabolic Syndrome } \\
\text { IDF }\end{array}$ & & $2.9 \pm 1.0$ & $1-5$ & $1.7 \pm 0.8$ & $0-4$ & 0.004 \\
\hline $\begin{array}{l}\text { Metabolic syndrome NCEP ATP III } \\
\text { absent/present }\end{array}$ & $\% 1 \%$ & $41.7 / 58.3$ & & $75.5 / 24.5$ & & 0.001 \\
\hline Metabolic Syndrome IDF absent/present & $\% / \%$ & $37.5 / 62.5$ & & $69.4 / 30.6$ & & 0.003 \\
\hline $\begin{array}{l}\text { PNPLA3 polymorphism } \\
(\mathrm{CC} / \mathrm{CG} / \mathrm{GG})\end{array}$ & $\mathrm{n}(\%)$ & $\begin{array}{l}73(58.2) / 47(37.7) / 5 \\
(4.1)\end{array}$ & & $\begin{array}{l}40(48.8) / 39(47.6) / 3 \\
(3.7)\end{array}$ & & $\mathrm{ns}$ \\
\hline CK 18 & $\mathrm{U} / \mathrm{L}$ & $218.5 \pm 24.4$ & $\begin{array}{l}45.1 \\
1781.0\end{array}$ & NA & & \\
\hline Serum adiponectin & $\mathrm{ng} / \mathrm{mL}$ & $10348.0 \pm 4849.9$ & $\begin{array}{l}4203 \\
23251\end{array}$ & $15076.3 \pm 7569.2$ & $\begin{array}{l}5137 \\
35091\end{array}$ & $\begin{array}{l}< \\
0.001\end{array}$ \\
\hline Serum leptin & $\mathrm{ng} / \mathrm{mL}$ & $55.25 \pm 15.84$ & $\begin{array}{ll}26.5 & - \\
108.7\end{array}$ & $33.66 \pm 8.64$ & $19.1-60.8$ & $\begin{array}{l}< \\
0.001\end{array}$ \\
\hline
\end{tabular}

678 Continuous variables are presented as mean \pm standard deviation. $p=p$-value of the

679 comparison between baseline and 1 year follow-up (paired samples t-test, Wilcoxon signed 680 ranks test or McNemar as appropriate on $\mathrm{n}=85$ ). $\mathrm{M}=$ male; $\mathrm{F}=$ female; $\mathrm{WHR}=$ waist-to-hip 681 ratio; $\mathrm{MABP}=$ mean arterial blood pressure; $\mathrm{LDH}=$ lactate dehydrogenase $;$ AST $=$ aspartate 682 aminotransferase; ALT = alanine aminotransferase; GGT = gamma glutamyl transpeptidase;

$683 \mathrm{HDL}=$ high density lipoprotein; $\mathrm{TG}=$ triglycerides; HBA1c = glycosylated haemoglobin;

684 HOMA IR $=$ homeostasis model of assessment insulin resistance; USS $=$ ultrasound steatosis 
685 score; ABT = aminopyrine breath test; $\mathrm{y} / \mathrm{n}=$ yes or no; NCEP ATP III = US Third Adult

686 Treatment Panel of the National Cholesterol Education Program; IDF = International Diabetes

687 Federation; $\mathrm{CK}=$ cytokeratin, PNPLA3 = patatin like phospholipase domain-containing

688 protein $3 ; \mathrm{NA}=$ not available $; \mathrm{ns}=$ not significant

689

690 
691 Table 2. Histological characteristics of the patient cohort at baseline $(n=125)$ and

692 follow-up $(\mathbf{n}=\mathbf{8 5})$.

\begin{tabular}{|c|c|c|c|c|c|c|c|c|}
\hline \multirow{2}{*}{ Histological feature } & \multirow[b]{2}{*}{ Range } & \multicolumn{2}{|c|}{$\begin{array}{l}\text { Baseline } \\
n=125\end{array}$} & \multicolumn{2}{|c|}{$\begin{array}{l}\text { Baseline } \\
\mathrm{n}=85\end{array}$} & \multicolumn{2}{|c|}{$\begin{array}{c}\text { Follow-up } \\
n=85\end{array}$} & \multirow[t]{2}{*}{$\mathbf{p}$} \\
\hline & & $\mathbf{n}$ & $\%$ & $\mathrm{n}$ & $\%$ & $\mathrm{n}$ & $\%$ & \\
\hline \multirow[t]{4}{*}{ Steatosis } & 0 & 38 & 30.4 & 15 & 17.6 & 56 & 65.9 & \multirow{4}{*}{$<0.001$} \\
\hline & 1 & 34 & 27.2 & 31 & 36.5 & 17 & 20.0 & \\
\hline & 2 & 32 & 25.6 & 18 & 21.2 & 11 & 12.9 & \\
\hline & 3 & 21 & 16.8 & 21 & 24.7 & 1 & 1.2 & \\
\hline \multirow[t]{9}{*}{ NAS } & 0 & 20 & 16.0 & 8 & 9.4 & 49 & 57.6 & \multirow[t]{9}{*}{$<0.001$} \\
\hline & 1 & 14 & 11.2 & 5 & 5.9 & 5 & 5.9 & \\
\hline & 2 & 17 & 13.6 & 11 & 12.9 & 7 & 8.2 & \\
\hline & 3 & 17 & 13.6 & 11 & 12.9 & 8 & 9.4 & \\
\hline & 4 & 15 & 12.0 & 16 & 18.8 & 5 & 5.9 & \\
\hline & 5 & 16 & 12.8 & 9 & 10.6 & 5 & 5.9 & \\
\hline & 6 & 14 & 11.2 & 17 & 20.0 & 5 & 5.9 & \\
\hline & 7 & 10 & 8.0 & 7 & 8.2 & 1 & 1.2 & \\
\hline & 8 & 2 & 1.6 & 1 & 1.2 & 0 & 0 & \\
\hline \multirow{2}{*}{ NASH according to Chalasani } & No NASH & 63 & 50.4 & 51 & 60 & 73 & 86.9 & \multirow[t]{2}{*}{$<0.001 *$} \\
\hline & NASH & 62 & 49.6 & 34 & 40 & 11 & 13.1 & \\
\hline \multirow{3}{*}{ NAS-based classification } & No NASH & 51 & 40.8 & 24 & 28.2 & 61 & 71.8 & \multirow[t]{3}{*}{$<0.001$} \\
\hline & Borderline NASH & 32 & 25.6 & 27 & 31.8 & 13 & 15.3 & \\
\hline & Definite NASH & 42 & 33.6 & 34 & 40.0 & 11 & 12.9 & \\
\hline \multirow{5}{*}{ Fibrosis stage } & 0 & 75 & 60.0 & 49 & 57.6 & 65 & 76.5 & \multirow[t]{5}{*}{0.011} \\
\hline & 1 & 21 & 16.8 & 17 & 20.0 & 10 & 11.8 & \\
\hline & 2 & 19 & 15.2 & 11 & 12.9 & 5 & 5.9 & \\
\hline & 3 & 9 & 7.2 & 8 & 9.4 & 2 & 2.4 & \\
\hline & 4 & 1 & 0.8 & 0 & 0 & 3 & 3.5 & \\
\hline
\end{tabular}

693

694 
695 The distribution of the patients according to the degree of steatosis, the stage of fibrosis, the 696 NAS, the presence of NASH according to Chalasani et al and the classification as no 697 NASH/borderline NASH/definite NASH based on the NAS as proposed by Kleiner et al are 698 listed as absolute numbers (n) and percentages $(\%)$ for the overall baseline cohort $(n=125)$ 699 and for the cohort of patients with paired baseline and 1 year follow-up biopsy $(\mathrm{n}=85)$. 700 Baseline and follow-up data were compared using non-parametric paired samples Wilcoxon 701 signed ranks test or McNemar $(*)$ test. NAS = NAFLD actvity score; NASH = non-alcoholic 702 steatohepatitis, $\mathrm{p}=\mathrm{p}$-value of the comparison between baseline and follow-up.

703

704 
705 Table 3. Factors that significantly correlate with PPAR expression in liver tissue at

706 baseline $(\mathbf{n}=\mathbf{1 2 5})$.

\begin{tabular}{|c|c|c|c|}
\hline & $\operatorname{PPAR} \alpha$ & PPAR $\beta \delta$ & PPAR $\gamma$ \\
\hline & $\mathrm{R}^{2}(\mathrm{p})$ & $\mathrm{R}^{2}(\mathrm{p})$ & $\mathrm{R}^{2}(\mathrm{p})$ \\
\hline BMI & $-0.238(0.008)$ & & \\
\hline Waist & $-0.381(<0.001)$ & & \\
\hline WHR & $-0.343(<0.001)$ & & \\
\hline Total adipose tissue & $-0.237(0.008)$ & & \\
\hline Visceral adipose tissue & $-0.334(<0.001)$ & & \\
\hline Total Cholesterol & $0.179(0.046)$ & & \\
\hline TG & $-0.181(0.047)$ & & \\
\hline $\mathrm{LDH}$ & & & $0.290(0.033)$ \\
\hline AST & & & $0.312(0.019)$ \\
\hline GGT & $-0.207(0.020)$ & & \\
\hline Bilirubine total & & & $0.292(0.030)$ \\
\hline Thrombocytes & & & $-0.321(0.018)$ \\
\hline INR & & & $0.289(0.032)$ \\
\hline PAI1 & & & $0.325(0.016)$ \\
\hline HBA1c & $-0.181(0.045)$ & & \\
\hline Fasting insulin & $-0.466(<0.001$ & & \\
\hline Fasting C-peptide & $-0.441(\mathrm{p}<0.001)$ & & \\
\hline Quicki index & $0.462(<0.001)$ & & \\
\hline HOMA & $-0.411(\mathrm{p}<0.001)$ & & \\
\hline USS & $-0.261(0.007)$ & & \\
\hline ABT peak excretion & $0.209(0.022)$ & & \\
\hline ABT cumulative excretion & $0.209(0.009)$ & & \\
\hline Adiponectin & $0.345(0.010)$ & $0.374(0.005)$ & \\
\hline CK18 & -0.233 & & \\
\hline Gender & & & $0.377(0.004)$ \\
\hline
\end{tabular}




\begin{tabular}{|l|l|l|l|}
\hline PNPLA3 & $0.253(0.005)$ & \\
\hline
\end{tabular}

707

708

709 The different antropometrical, biochemical or other factors (excluding histology) that

710 significantly correlate with the expression of PPAR $\alpha, \operatorname{PPAR} \beta / \delta$ and PPAR $\gamma$ in liver tissue in

711 the baseline cohort $(n=125)$ are listed. $R^{2}=$ Spearman correlation coëfficiënt (continous

712 variables) or adjusted $\mathrm{R}$ square of the lineary logistic regression (catogorical variables); $\mathrm{p}=\mathrm{p}$ -

713 value of the correlation or univariate linear regression; BMI = body mass index; WHR =

714 waist-to-hip ratio; $\mathrm{MS}=$ metabolic syndrome; $\mathrm{LDH}=$ lactate dehydrogenase; AST = aspartate

715 aminotransferase; ALT = alanine aminotransferase; GGT = gamma glutamyl transpeptidase;

$716 \mathrm{HDL}=$ high density lipoprotein; $\mathrm{TG}=$ triglycerides; $\mathrm{LDL}=$ low density lipoprotein; HBA1c

$717=$ glycosylated haemoglobin; $\mathrm{INR}=$ international normalized ratio; $\mathrm{PAI}-1=$ tissue

718 plasminogen activator inhibitor 1; QUICKI = quantitative assessment check index calculated

719 as $1 /[\log ($ fasting insulin $)+\log ($ fasting glucose $)] ;$ HOMA IR $=$ homeostasis model of

720 assessment insulin resistance calculated as [fasting insulin (mU/L) $\mathrm{x}$ fasting glucose

$721(\mathrm{mmol} / \mathrm{L})] / 22.5 ;$ USS = ultrasound steatosis score; $\mathrm{ABT}=$ aminopyrine breath test; $\mathrm{NCEP}$

722 ATP III = US Third Adult Treatment Panel of the National Cholesterol Education Program;

723 CK18 = cytokeratin 18; PNPLA3 = patatin like phospholipase domain-containing protein 3;

724 PPAR = peroxisome proliferator activator receptor. 
Table 4. Main baseline and $1 \mathrm{y}$ follow-up characteristics of the patients with paired liver

728 biopsies according to the type of treatment.

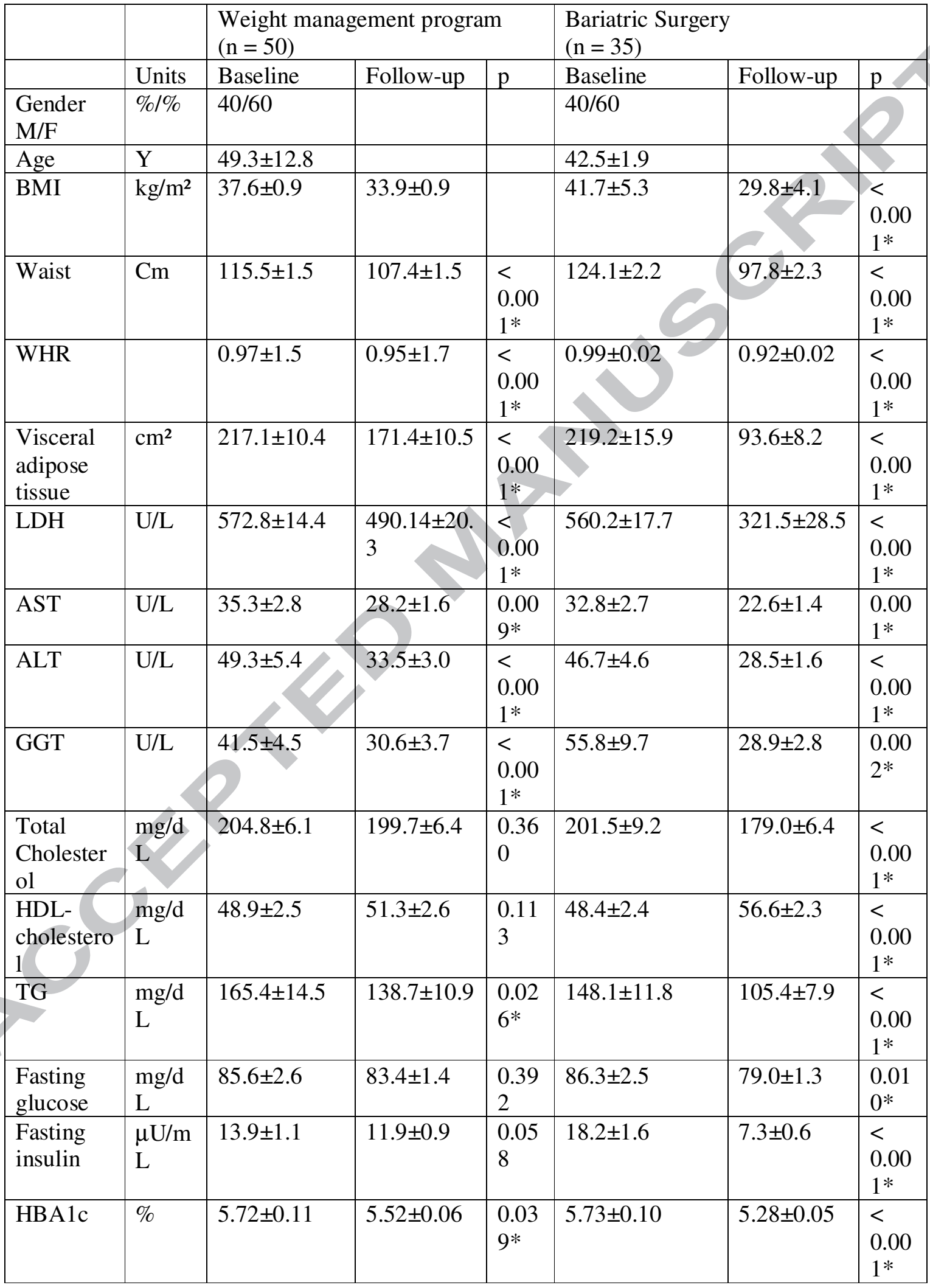


ACCEPTED MANUSCRIPT

\begin{tabular}{|c|c|c|c|c|c|c|c|}
\hline $\begin{array}{l}\text { HOMA } \\
\text { IR }\end{array}$ & & $2.97 \pm 0.26$ & $2.50 \pm 0.23$ & $\begin{array}{l}0.07 \\
5\end{array}$ & $4.04 \pm 0.44$ & $1.42 \pm 0.12$ & $\begin{array}{l}< \\
0.00 \\
1 *\end{array}$ \\
\hline USS & & $2.13 \pm 0.15$ & $1.43 \pm 0.15$ & $\begin{array}{l}< \\
0.00 \\
1 *\end{array}$ & $2.21 \pm 0.15$ & $0.50 \pm 0.12$ & $\begin{array}{l}< \\
0.00 \\
1 *\end{array}$ \\
\hline $\begin{array}{l}\text { ABT } \\
\text { peak } \\
\text { excretion }\end{array}$ & $\%$ & $9.28 \pm 0.58$ & $12.21 \pm 0.81$ & $\begin{array}{l}< \\
0.00 \\
1 *\end{array}$ & $8.43 \pm 0.61$ & $9.83 \pm 0.73$ & $\begin{array}{l}0.03 \\
5^{*} \\
\end{array}$ \\
\hline $\begin{array}{l}\text { ABT } \\
\text { cumulativ } \\
\text { e } \\
\text { excretion }\end{array}$ & $\%$ & $13.34 \pm 0.79$ & $17.72 \pm 1.14$ & $\begin{array}{l}< \\
0.00 \\
1 *\end{array}$ & $12.12 \pm 0.97$ & $14.9 \pm 1.05$ & $\begin{array}{l}0.00 \\
4^{*}\end{array}$ \\
\hline $\begin{array}{l}\text { Number } \\
\text { criteria } \\
\text { Metabolic } \\
\text { syndrome } \\
\text { NCEP } \\
\text { ATP III } \\
\end{array}$ & & $2.35 \pm 0.18$ & $1.85 \pm 0.19$ & $\begin{array}{l}0.00 \\
6^{*}\end{array}$ & $2.65 \pm 0.24$ & $1.24 \pm 0.24$ & $\begin{array}{l}< \\
0.00 \\
1 *\end{array}$ \\
\hline $\begin{array}{l}\text { Metabolic } \\
\text { syndrome } \\
\text { NCEP } \\
\text { ATP III } \\
\text { absent/pre } \\
\text { sent }\end{array}$ & $\% / \%$ & $49 / 51$ & $68 / 32$ & 0.58 & $45.5 / 54.5$ & $88.9 / 11.1$ & $\begin{array}{l}0.00 \\
2^{*}\end{array}$ \\
\hline $\begin{array}{l}\text { PNPLA3 } \\
\text { polymorp } \\
\text { hism } \\
\text { (CC/CG/ } \\
\text { GG) }\end{array}$ & $\mathrm{n}(\%)$ & $\begin{array}{l}24(48) / 23(46 \\
) / 3(6)\end{array}$ & & & $\begin{array}{l}16(48.5) / 16(48 . \\
5) / 1(3)\end{array}$ & & \\
\hline $\begin{array}{l}\text { Serum } \\
\text { adiponect } \\
\text { in }\end{array}$ & $\begin{array}{l}\mathrm{ng} / \mathrm{m} \\
\mathrm{L}\end{array}$ & $\begin{array}{l}9892.3 \pm 1034 \\
.2\end{array}$ & $\begin{array}{l}14339.9 \pm 1 \\
581.0\end{array}$ & $\begin{array}{l}< \\
0.00 \\
1 *\end{array}$ & $9683.8 \pm 2508.6$ & $\begin{array}{l}19494.3 \pm 2 \\
516.6\end{array}$ & $\begin{array}{l}0.01 \\
6^{*}\end{array}$ \\
\hline $\begin{array}{l}\text { PPAR } \alpha \\
\text { expressio } \\
n\end{array}$ & & $0.295 \pm 0.041$ & $\begin{array}{l}0.375 \pm 0.04 \\
7\end{array}$ & $\begin{array}{l}0.03 \\
9 *\end{array}$ & $0.331 \pm 0.027$ & $\begin{array}{l}0.66 \pm 0.0 .4 \\
73\end{array}$ & $\begin{array}{l}< \\
0.00 \\
1 *\end{array}$ \\
\hline Steatosis & $\begin{array}{l}0 / 1 / 2 / \\
3\end{array}$ & $7 / 19 / 11 / 13$ & $21 / 17 / 11 / 1$ & $\begin{array}{l}< \\
0.00 \\
1 *\end{array}$ & $8 / 12 / 7 / 8$ & $35 / 0 / 0 / 0$ & $\begin{array}{l}< \\
0.00 \\
1 *\end{array}$ \\
\hline $\begin{array}{l}\text { Lobular } \\
\text { inflammat } \\
\text { ion }\end{array}$ & $\begin{array}{l}0 / 1 / 2 / \\
3\end{array}$ & $11 / 24 / 10 / 5$ & $26 / 14 / 9 / 1$ & $\begin{array}{l}< \\
0.00 \\
1 *\end{array}$ & $10 / 11 / 13 / 1$ & $33 / 2 / 0 / 0$ & $\begin{array}{l}< \\
0.00 \\
1 *\end{array}$ \\
\hline $\begin{array}{l}\text { Balloonin } \\
\mathrm{g}\end{array}$ & $0 / 1 / 2$ & $8 / 18 / 24$ & $21 / 18 / 11$ & $\begin{array}{l}< \\
0.00 \\
1 *\end{array}$ & $11 / 15 / 9$ & $31 / 2 / 2$ & $\begin{array}{l}< \\
0.00 \\
1 *\end{array}$ \\
\hline NAS & & $4.1 \pm 0.3$ & $2.3 \pm 0.3$ & $\begin{array}{l}< \\
0.00 \\
1 * \\
\end{array}$ & $3.51 \pm 0.38$ & $0.23 \pm 0.12$ & $\begin{array}{l}< \\
0.00 \\
1 * \\
\end{array}$ \\
\hline Fibrosis & $0 / 1 / 2 /$ & $37 / 7 / 4 / 0 / 2$ & $34 / 8 / 4 / 4 / 0$ & 0.41 & $15 / 9 / 7 / 4 / 0$ & $28 / 3 / 1 / 2 / 1$ & 0.00 \\
\hline
\end{tabular}




\begin{tabular}{|l|l|l|l|l|l|l|l|}
\hline stage & $3 / 4$ & & & 7 & & & $9 *$ \\
\hline No & & $16 / 34$ & $27 / 23$ & 0.00 & $15 / 20$ & 35 & $<$ \\
NASH/N & & & & $6 *$ & & & 0.00 \\
ASH & & & & & & & $1 *$ \\
\hline
\end{tabular}

729

730

\section{1}

732

733

734

735

736

737

738

739

740

741

742

743

744

745

746

747

The main characteristics of the patients, including the histological characteristics and the presence of NASH according to Chalasani et al are listed for the cohort of patients with paired baseline and 1 year follow-up biopsy $(n=85)$ according to their treatment. Continuous variables are presented as mean \pm standard error of the mean. Histological characteristics are presented as distributions, except for NAS. $\mathrm{p}=\mathrm{p}$-value of the comparison between baseline and 1 year follow-up (paired samples t-test, Wilcoxon signed ranks test or McNemar as appropriate). $\mathrm{M}=$ male; $\mathrm{F}=$ female WHR = waist-to-hip ratio; $\mathrm{LDH}=$ lactate dehydrogenase; $\mathrm{AST}=$ aspartate aminotransferase $;$ ALT $=$ alanine aminotransferase $;$ GGT $=$ gamma glutamyl transpeptidase; $\mathrm{HDL}=$ high density lipoprotein; $\mathrm{TG}=$ triglycerides $; \mathrm{HBA} 1 \mathrm{c}=$ glycosylated haemoglobin; HOMA IR = homeostasis model of assessment insulin resistance; USS = ultrasound steatosis score; $\mathrm{ABT}=$ aminopyrine breath test; $\mathrm{y} / \mathrm{n}=$ yes or no; NCEP ATP III = US Third Adult Treatment Panel of the National Cholesterol Education Program; PNPLA3 = patatin like phospholipase domain-containing protein 3 ; PPAR $=$ peroxisome proliferator activator receptor; NAS $=$ NAFLD activity Score; NASH = Non-Alcoholic Steatohepatitis; * $=$ statistically significant $(\mathrm{p}<0.05)$ 